\title{
A mobile DNA laboratory for forensic science adapted to coronavirus SARS-CoV-2 diagnosis
}

\author{
Patrick Touron ${ }^{1,2} \cdot$ Christian Siatka $^{3,4}$ - Amaury Pussiau ${ }^{2} \cdot$ Sébastien Follot $^{2} \cdot$ Thibaud Fritz $^{2} \cdot$ Mikaël Petit $^{1}$. \\ Noussair Latifa $^{5}$ - Jean-Louis Herrmann ${ }^{5}$ - Martin Rottman ${ }^{5}$ • Antoinette Lemoine ${ }^{6}$. Sylvain Hubac ${ }^{2,4}$
}

Received: 18 May 2020 / Accepted: 9 July 2020 / Published online: 14 July 2020

(C) Springer-Verlag GmbH Germany, part of Springer Nature 2020

\begin{abstract}
The Forensic Science Institute of the French "Gendarmerie Nationale" (IRCGN"M) developed in 2015 an ISO 17025 certified mobile DNA laboratory for genetic analyses. This Mobil'DNA laboratory is a fully autonomous and adaptable mobile laboratory to perform genetic analyses in the context of crime scenes, terrorism attacks or disasters. To support the hospital task force in Paris during the peak of the COVID-19 epidemic, we adapted this mobile genetic laboratory to perform high-throughput molecular screening for coronavirus SARS-CoV-2 by real-time PCR. We describe the adaptation of this Mobil'DNA lab to assist in Coronavirus SARS-CoV-2 diagnosis.
\end{abstract}

\section{Introduction}

On March 11, 2020, the World Health Organization (WHO) classified the outbreak due to severe acute respiratory syndrome coronavirus 2 (SARS-CoV-2) as a public health emergency. This epidemic has indeed taken on the proportions of a pandemic (WHO, March 2020) [1]. The viral pathology linked to this Coronavirus was described in China for the first time in December 2019 and named COVID-19 (coronavirus disease 2019) [2]. Quickly, this disease fuelled a massive and legitimate interest, especially in terms of specific molecular diagnosis capabilities. The clinical consequences are multiple and variable but most importantly feature an acute respiratory

Sylvain Hubac

sylvain.hubac@gendarmerie.interieur.gouv.fr

1 PJGN, 5 Boulevard de l'Hautil, 95000 Cergy, France

2 IRCGN, 5 Boulevard de 1'Hautil, 95000 Cergy, France

3 Université de Nîmes, 7 Place Gabriel Péri, 30000 Nîmes, France

4 Ecole de l'ADN, 19 grand rue, Muséum d'Histoire Naturelle, 30000 Nîmes, France

5 Assistance Publique-Hôpitaux de Paris INSERM U1173, UFR Simone Veil, Versailles-Saint-Quentin University, 78180 Saint-Quentin en Yvelines, France

6 Département Médical Universitaire de Biologie-Génétique-Pharmacie, AP-HP, Université Paris Saclay, 78 rue du Général Leclerc, 94270 Le Kremlin-Bicêtre, France distress syndrome (ARDS), which can be associated with multi-organ failure with myocardial, renal, enteric and hepatic lesions, possibly leading to death, particularly in elderly patients with comorbidities [3]. SARS-CoV-2 transmission has affected more than 2.85 million people and caused more than 196,000 deaths worldwide as of April 27, 2020, including more than 22,500 in France (www.who.int). For these reasons, monitoring COVID-19 is important and strategic [4].

\section{An ISO 17025 certified lab: the Mobil'DNA}

In 2015, the French "Gendarmerie Nationale" patented (FR3050945B1) a Mobil'DNA lab for genetic forensic analysis which allows magistrates and investigators to quickly obtain genetic results. This mobile laboratory is transportable as close as possible to scenes of disasters, complex crime scenes or to places where people in police custody are gathered [5]. It has already been used for the identification of the victims of the GermanWings (2015) air crash and the 2016 Nice terror attack [6] where it carried out several hundred analyses per day.

This Mobil'DNA lab makes it possible to implement an analytical process for determining genetic profiles from a biological sample with a configuration which makes it possible to respect the principle of "forward movement" of the processing of a sample described as: 
- A sampling area, to manage and analyse the sample

- A PRE-PCR zone, in which the technical operations for the purification of nucleic acids and the preparation of nucleic acids for amplification by PCR or RT-PCR are carried out [7]

- A POST PCR area, in which both gene amplifications by PCR and RT-PCR are carried out and genotyping by capillary electrophoresis of nucleic acids [7]

\section{COVID-19 diagnosis: SARS-CoV-2 detection}

Since March 2020, French public health authorities stressed the need to rapidly expand the diagnostic capabilities for COVID-19. This global health crisis shows the need to mobilize a diagnostic force quickly at national and international level. These solutions must interface with clinical diagnostic laboratories to meet the quality standards for medical biology (ISO 15189) [8] and should be mobile to best address the needs. The French National Gendarmerie, as an interior security force serving the protection of the French people, has taken the initiative to adapt the forensic Mobil'DNA. The objective is to propose an autonomous mobile biomolecular laboratory for rapid tests at high-throughput level for the endemic pathogen SARS Cov-2, in support of local hospitals and health systems, in rural or confined areas and overseas.

To be efficient for this mobile force for microbiological diagnosis, the IRCGN combined its expertise in mobile and high-speed analysis of biological samples with the expertise of a French medical biology structure in the diagnosis of endemic pathogens.
The creation of a mixed unit composed of IRCGN and the Microbiology Department of Hospital Raymond Poincaré (GHU Paris Saclay, Assistance Publique-Hôpitaux de Paris) allowed the rapid adaptation IRCGN mobile DNA analysis laboratory in order to guarantee optimal conditions for operator safety, sample traceability and analysis sensitivity in order to detect the presence of COVID-19 by viral RNA analysis [9, 10]. This rapid adaptation is greatly facilitated by the convergence of analytical methods and ISO 17025/ISO 15189 normative requirements between the analysis of a human biological sample for DNA analysis and the analysis of this same biological sample for detecting a pathogen by targeting the RNA Coronavirus (see Fig. 1) [8]. This partnership was authorized by the ordinance of the French government on 5 April 2020 [11] giving the possibility to ISO 17025 certified laboratories to perform biomedical testing by RT-PCR in order to detect COVID-19 infection.

\section{Material and strategy}

\section{Validation process, sample processing and high- throughput COVID-19 detection by RT PCR}

Regarding this outbreak context, the Mobil'DNA lab of the French gendarmerie was adapted as a true extension of the fixed hospital laboratory by validating and following an analytical process.

The validation of the analytical process of the Mobil'DNA lab was carried out over a period of 10 days through comparative studies between the reference analytical technique used by the hospital and the analytical process performed by the
Fig. 1 The Mobil'DNA lab, the adaptation for genetic diagnosis (inside view)

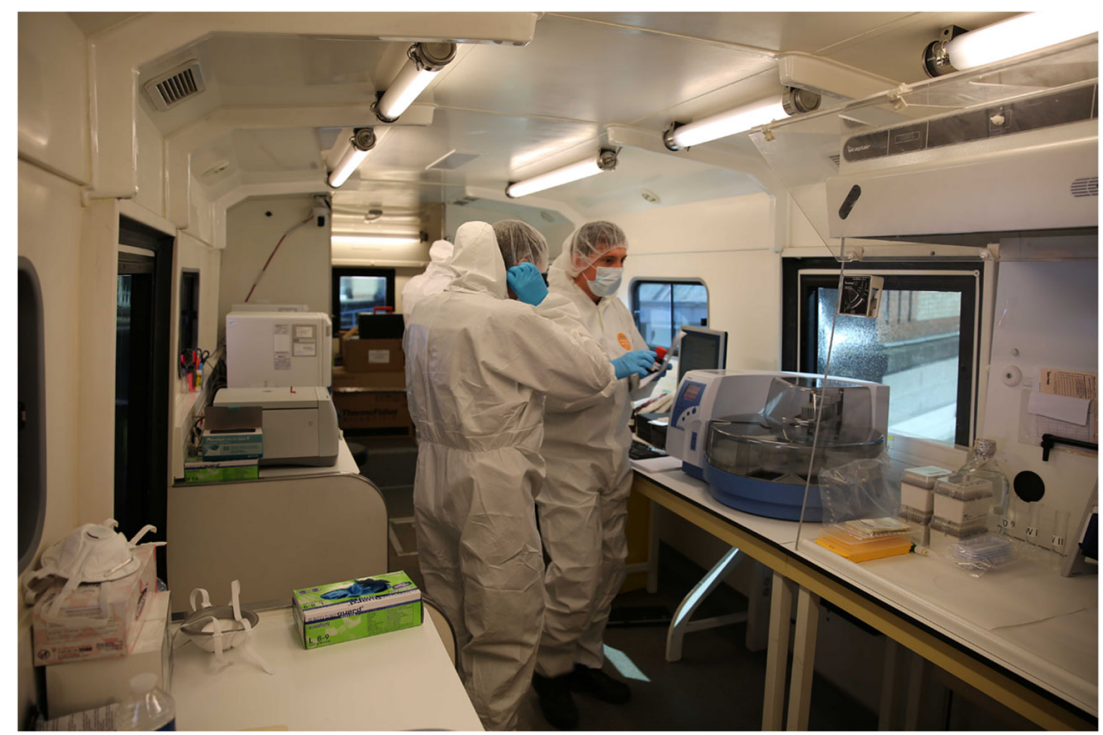


IRCGN [2]. To this end, the analytical parameters of the process were cleared with verification of sensitivity, of repeatability and of reproducibility, carried out on more than 100 prospective clinical samples. The lack of cross-contamination was verified at all stages with the assays of high concentration RNA extracts.

The analytical process is performed in 5 steps:

1. Taking samples and recording them for traceability on the basis of the unique barcode identifier. All is done using a computerized system LIMS, which is connected to the hospital unit in order to transfer automatically the results of the essays. It provides a complete overview and control of analytical data to the microbiologists.

2. Sampling a fraction of the biological sample to be analysed. This operation is carried out under a type 2 microbiological safety cabinet (MSC).

3. Extraction of the RNA contained in the sample by lysis of the virus using the hospital's procedures [10].

4. Quantification of purified DNA by real-time PCR (RTPCR) system.

5. Result interpretation and generation of reports, using GendLink ${ }^{\circledR}$ an original gendarmerie software adapted to generate a report on the results of COVID analyses.

In order to ensure operator safety against COVID-19, each operator is wearing a single-use personal protective equipment including an integral Tyvek type suit, a double pair of gloves (external pair changed between each sample), a surgical mask or an FFP2 type mask for steps 1 and 2, a hood and protective goggles.

The analyses are done on an Applied ${ }^{\mathrm{TM}} 7500$ real-time PCR system (software v2.3) according to the hospital procedure, using RNA extraction negative control, internal quality control (ICQ) composed by quantified virus RNA from patients diagnosed as COVID-19 infected, non-template control for RT-PCR and positive control from the GeneFirst ${ }^{\circledR}$ RUO COVID-19 Detection kit. In this configuration, the Mobil'DNA can provide a maximum of 1000 results per day involving five technical persons from IRCGN and 3 clinical microbiologists from the hospital to validate the results

\section{Results}

Since the validation of the technical procedure, on the 14 April 2020 at Garches Hospital, around 4000 samples were analysed in 14 days with throughput between 100 and 700 samples per day depending on the delivery of samples. After reception of the samples, the results are given in less than $24 \mathrm{~h}$. The Mobil'DNA lab and the forensic science laboratory of the French gendarmerie in the context of the COVID-19 pandemic can provide three short-term issues with a direct impact on this crisis:

1. The possibility within a short time of setting up an additional testing capacity to deal with a massive influx of individuals to be tested on a hospital site

2. To respond to a demand for test capacity in rural areas or overseas, for citizens distant from the test centres

3. To validate a global and efficient concept of mobile lab unit for rapid molecular diagnostic tests, easily transposable and deployable anywhere in the world during such outbreak scenario

\section{Conclusion}

Using this mixed concept mobile laboratory between the French National Gendarmerie and hospital centres has demonstrated the ability to pool skills and resources to cope with the current outbreak period by creating a single autonomous mobile solution, deployable in a very short time. This concept will provide an effective solution in the following cases:

- Mobile rapid diagnostic unit to be deployed on a remote site, isolated or contained contaminated areas, point of entry into the territory of a source of propagation of a pandemic (port, airport, border).

- Extension of diagnostic test capacities to other pathogens (viruses such as Ebola and dengue or bacteria such as cholera and the tuberculosis bacillus). IRCGN is at the cutting edge of technology, as are collaborating medical microbiologists. This will make it possible to deploy the most efficient technologies depending on the situations in areas that cannot be equipped in such a short time.

- The possibilities to extend the concept to other means of deployment (train, plane, etc.).

It shows that forensic police forces can collaborate with medical capabilities using the same technologies for the same purpose: health security and diagnostic assistance.

Acknowledgements The authors would like to thank Mr. Christophe Castaner, Minister of the Interior and General Christian RODRIGUEZ, Director General of the National Gendarmerie, who made it possible for the Gendarmerie Scientifique to work quickly with the AP-HP microbiologists to improve the detection capacity of COVID-19. We are also grateful to the Pr Philippe Berta, geneticis at Nîmes University and John Watson, expert for the European Commission, for their excellent technical assistance and reviewing.

\section{Compliance with ethical standards}

Conflict of interest Hubac S. is the owner of the patent of Mobil'DNA. 


\section{References}

1. Coronaviridae Study Group of the International Committee on Taxonomy of Viruses (2020) The species severe acute respiratory syndrome-related coronavirus: classifying 2019-nCoV and naming it SARS-CoV-2. Nat Microbiol 5:536-544. https://doi.org/10. 1038/s41564-020-0695-Z

2. Huang C, Wang Y, Li X, Ren L, Zhao J, Hu Y et al (2020) Clinical features of patients infected with 2019 novel coronavirus in Wuhan, China. Lancet 395:497-506. https://doi.org/10.1016/S01406736(20)30183-5

3. Chen N, Zhou M, Dong X, Qu J, Gong F, Han Y et al (2020) Epidemiological and clinical characteristics of 99 cases of 2019 novel coronavirus pneumonia in Wuhan, China: a descriptive study. Lancet 395:507-513. https://doi.org/10.1016/S01406736(20)30211-7. Accessed 7 may 2020

4. CDC. Coronavirus Disease 20192020 (COVID-19) [Internet]. Centers for Disease Control and Prevention 11 [cited 2020 24]; https://www.cdc.gov/coronavirus/2019-ncov/hcp/testingoverview.html

5. de Boer HH, Blau S, Delabarde T, Hackman L (2019) The role of forensic anthropology in disaster victim identification (DVI): recent developments and future prospects. Forensic Sci Res 4:303-315. https://doi.org/10.1080/20961790.2018.1480460
6. Gaudry E, Dourel L, Conigliaro A, Georget C, Desbrosse X, Hubac S (2017) L'identification de victimes de catastrophe : une approche scientifique pluridisciplinaire. Rev Fr Lab 2017:41-57. http://www. sciencedirect.com/science/article/pii/S1773035X17300291. https:// doi.org/10.1016/S1773-035X(17)30029-1

7. Honsa JD, McIntyre DA (2003) ISO 17025: practical benefits of implementing a quality system. J AOAC Int 86:1038-1044

8. Ho B (2004) Practical application of ISO 15189 by accreditation bodies -: a comparison with ISO/IEC 17025. EJIFCC 15:128-135

9. Gao Y, Yan L, Huang Y, Liu F, Zhao Y, Cao L et al (2020) Structure of the RNA-dependent RNA polymerase from COVID19 virus. Science 368:779-782. https://doi.org/10.1126/science. abb7498

10. Wölfel R, Corman VM, Guggemos W, Seilmaier M, Zange S, Müller MA et al (2020) Virological assessment of hospitalized patients with COVID-2019. Nature 581:465-469. https://doi.org/ 10.1038/s41586-020-2196-X

11. Arrêté du 5 avril 2020 complétant l'arrêté du 23 mars 2020 prescrivant les mesures d'organisation et de fonctionnement du système de santé nécessaires pour faire face à l'épidémie de covid-19 dans le cadre de l'état d'urgence sanitaire

Publisher's note Springer Nature remains neutral with regard to jurisdictional claims in published maps and institutional affiliations. 